\title{
Reduced vision caused by choroid osteoma
}

\author{
Baixa visão secundária a osteoma de coroide
}

Thiago Gonçalves dos Santos Martins ${ }^{1}$, Ana Luiza Fontes de Azevedo Costa ${ }^{2}$, Celina Bahiense Barreira Lins ${ }^{3}$, Ian Curi Bonotto de Oliveira Costa 3 , Mario Martins dos Santos Motta ${ }^{3}$

\begin{abstract}
The authors present a case of choroidal osteoma diagnosed in a 25-year-old female patient. A well-defined and slightly elevated yellow lesion located in the posterior pole of the right eye was suspected to be a tumor. Confirmation of diagnosis was obtained with $A$ and $B$ ecography. The patient had low vision and macular edema, which improved after intraocular injection of bevacizumab .

Keywords: Choroid neoplasms/diagnosis; Choroid neoplasms/ultrasonography; Osteoma/diagnosis; Osteoma/ultrasonography; Low vision; Case reports
\end{abstract}

\section{Resumo}

Relatamos um caso de osteoma de coroide em uma paciente feminina de 25 anos. Apresentava uma lesão amarelada e elevada no polo posterior, característica da lesão tumoral. O diagnóstico foi confirmado com a ultrassonografia ocular. A paciente apresentava baixa acuidade visual e edema de mácula, que melhorou após injeção intravítrea de bevacizumab.

Descritores: Neoplasias da coroide/diagnóstico; Neoplasias da coroide/ultrassonografia; Osteoma/diagnóstico; Osteoma/ ultrassonografia; Baixa de visão; Relatos de casos

\footnotetext{
${ }^{1}$ Universidade Federal de São Paulo, São Paulo, SP, Brazil.

2 Universidade de São Paulo, São Paulo, SP, Brazil.

${ }^{3}$ Hospital Federal Servidores do Estado do Rio de Janeiro, Rio de Janeiro, RJ, Brazil.
}

The authors declare no conflicts of interests.

Received for publication 08/01/2015 - Accepted for publication 16/03/2015 


\section{INTRODUCTION}

$\mathbf{C}$ horoid osteoma is a benign, unilateral or bilateral acquired tumor which is presented as a choroidal mass of slow growth in the juxtapapillary region. The pathological characteristic of choroid osteoma is a mature bone plate around the optical disc reaching the entire thickness of the choroid, and generally sparing the retinal pigment epithelium. This benign tumor can cause loss of vision due to the subfoveal location, retinal serous detachment and neovascularization of the choroid. (1)

\section{CASe RePOrt}

Female patient aged 25 has complained of low visual acuity in the right eye for 4 years. She denied personal and family background of eye or systemic diseases.

The ophthalmological exam showed corrected visual acuity of 20/200 in the right eye and 20/20 in the left eye. The biomicroscopy was normal, and the intraocular pressure was $16 \mathrm{mmHg}$ in both eyes. The funduscopic exam evidenced macular lesion and welldelimited yellowish papilomacular beam in the right eye (Figure 1). There was no fundoscopic change in the left eye.

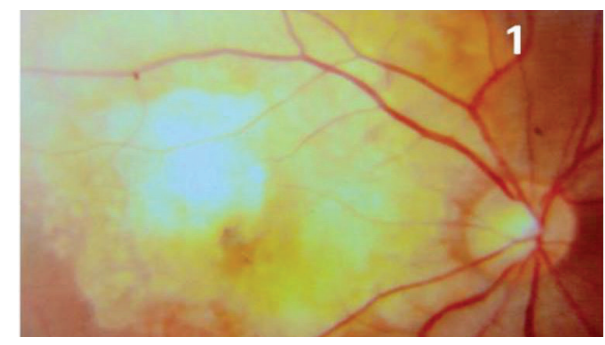

Figure 1: The retinography shows a well-delimited yellowish lesion in the posterior pole of the right eye

The optical coherence tomography showed a thickening of the pigment epithelium complex of the retina-choriocapillaris of high reflectivity and well delimited, with areas of elevation of the retinal pigment epithelium and detachment and edema of the neurosensory retina (Figure 2).

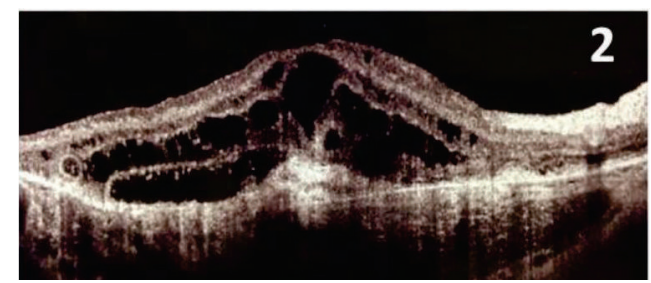

Figure 2: The optical coherence tomography of the posterior pole shows a well-delimited, highly reflective elevated structure in the area of the complex EPR-choriocapillaris. There are elevation areas of the EPR and neurosensory detachment.

Ultrasounds A and B showed a slightly elevated lesion of the posterior pole, with acoustic peak of high reflectivity on its inner surface and orbital acoustic shadowing posterior to it (Figure 3). The diagnostic hypothesis was choroid osteoma with secondary neovascular membrane and intra- and subretinal edema. After injection of $0.1 \mathrm{ml}$ of bevacizumabe, the patient improved the vision to 20/60 in the affected eye and reduced the swelling in the macular region (Figure 4).

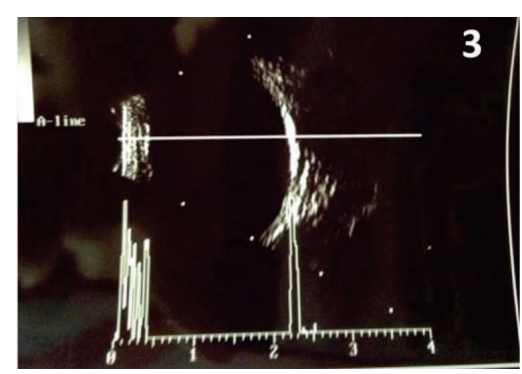

Figure 3: The sonographic appearance shows a high reflectivity peak on the inner surface and an acoustic shadowing posterior to the orbital tumor.

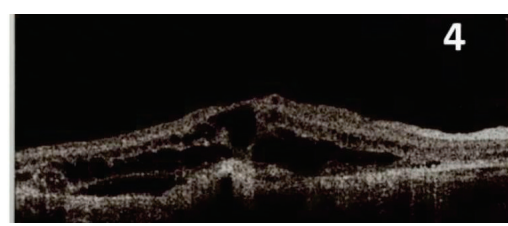

Figure 4: The optical coherence tomography of posterior pole shows an elevated structure reducing the edema area.

\section{Discussion}

Choroid osteoma is a benign tumor composed of mature bone tissue. It is rare, unilateral in $75 \%$ of cases, and more prevalent in women between 20 and 30 years old. ${ }^{[1]}$

It is a yellow or orange lesion, well delimited and of variable format located on the posterior pole. Its diameter and thickness reach maximum values of $2.2 \mathrm{~mm}$ and $2.5 \mathrm{~mm}$. The neovascularization of the choroid is a frequent complication of the choroid osteoma ${ }^{[2-4]}$.

The ultrasound is typical and shows increased reflectivity on the surface of the tumor and acoustic silence posterior to it. $[1,2]$.

The optical coherence tomography (OCT) is a non-invasive evaluation method that provides precise details of the retinal and coriocapilar architecture. Its application in cases of choroid osteoma is still poorly described in the literature ${ }^{[5,6]}$.

The ocular ultrasound was essential to the diagnosis of choroid osteoma, since the optical coherence tomography was used in order to get details of its architecture.

\section{ReferenCES}

1. Shields CL. Choroidal osteoma. In: Guyer DR, Yanuzzi LA, Chang, Shields Já, Green WR, editors. Retina- vitreous- macula. Philadelphia: WB Saunders; 1999. p. 1092-102.

2. Shields L, Shields JÁ, Augsburger JJ. Choroidal osteoma. Surv Ophthalmol. 1988;33 (1): 17-27. Review.

3. Gass JD. New observations concerning choroidal osteomas. Int Ophthalmol. 1979;1(2):71-84.

4. Coston TO, Wilkinson CP. Choroidal osteoma. Am J Ophthalmol. 1978;86(3):368-72.

5. Ide T, Ohguro N, Hayashi A, Yamamoto S, Nakagawa Y, Nagae Y, Tano Y.Optical coherence tomography patterns of choroidal osteoma. Am J Ophthalmol. 2000;130(1):131-4.

6. Fusawa A, Iijima H. Optical coherence tomography of choroidal osteoma. Am J Ophthalmol. 2002;133 (3): 419-21.

\section{Corresponding author:}

Thiago Gonçalves dos Santos Martins

R. Botucatu, 82-Vila Clementino, São Paulo, SP, Brazil. ZIP

Code: 04023-062

Phone: 552125712248

E-mail: thiagogsmartins@yahoo.com.br 